\title{
SHORTER ARTICLES
}

\section{Suspension and the non-striking worker}

\author{
John Hughes*
}

Section 128 of the Industrial Relations Act 1973 allows an employer to suspend nonstriking workers where work normally performed by them is not available because of a strike. This article considers the background to, and the case law arising from, such suspensions and the limitations that have been established on the employers power to suspend such workers.

\section{Introduction: The Political Context}

Section 128 subsection 1 of the Industrial Relations Act, 1973, as amended, states that

Where there is a strike, and as a result of the strike any employer is unable to provide

for any workers who are in his employment and not on strike work that is normally

performed by them, the employer may suspend their employment until the strike is ended.

The legal consequence of such suspension is set out in subsection 2 of section 128 . Such a worker will not be entitled to any remuneration during the period of suspension but, on the resumption of employment, the worker's service will be deemed to have been continuous for the purpose of any rights and benefits that are conditional upon such continuity.

Section 128 owes its origin to the Industrial Relations Bill 1972 into which it was introduced, in the words of one commentator, "in order to provide a legal basis and machinery for an already existing practice" of laying off workers in these circumstances (Hansen, 1974 , p. 318 ); the existence of the practice may explain the description of the original clause in the 1972 Bill by the then Minister of Labour as being simply one which "protects the superannuation and other rights of workers unfortunately caught up in a strike to which they are not parties". (NZPD (1972) 381 p. 3478) While the Bill was before the Select Committee there was a change in government and the incoming Labour Government amended the clause providing for a right to suspend by requiring the employer to give at least one week's notice before such a suspension took effect. Following the 1975 election the requirement for notice was removed by section 3 of the Industrial Relations Amendment Act 1976 (No. 1). The Act also widened the definition of what constituted "strike" action. (Woods, 1976; Reid, 1977; Szakats, 1977) One of the reasons advanced for the failure of the existing suspension provision was what was then said to be a "narrow" definition of "strike". The aim of removing the minimum period of notice was ostensibly "to provide employers with a means of countering, amongst other things, a rolling stoppage situation, and to recognise that an employer should not be liable to pay the wages of nonstriking workers from the time work is unavailable". (NZPD (1976) 405 p. 1701) There appeared to be a further objective, this being to bring pressure to bear upon those whom the Government regarded as "militant elements" within unions from workers who had been suspended as a result of strike action. (NZPD (1976) 405 p. 1722)

The weight given to this further objective may be assessed by considering the contemporaneous passage of the Social Security Amendment Act 1976, section 11 of which granted discretion to the Social Security Commission to postpone the commencement of an unemployment benefit for a period not exceeding six weeks where, amongst other things, " $[t]$ he applicant has lost his employment by reason of a strike either by himself or by fellow members of his union at the same place of employment". Just as the statutory intro-

* Lecturer in Law, University of Canterbury. 
duction of suspension was said to confirm existing industrial practice, so this provision was said to reflect "the long-standing policy of successive Governments and ... dispel . . . any doubts about legislative authority for this policy". (NZPD (1976) 406 p. 2571) It is questionable whether "the longstanding policy" referred to was ever applied strictly to workers unemployed as an indirect result of a dispute, but, as early as 1970, the Social Security Commission recommended to the Royal Commission on Social Security in New Zealand that the law needed strengthening to give specific authority when determining the entitlement to unemployment benefit of workers who lost their jobs through industrial action. (Social Security Department, 1970) The Royal Commission's view that this was a "political problem which ... calls for a political decision" and that the existing law was "as specific as the law needs to be, or can be" (Social Security in New Zealand (1974), p. 298), nevertheless met with a "political decision" that the law should be amended and made more specific. The 1976 amendment went beyond the existing rationale of ensuring that benefit should not be made available to those who were responsible for their own unemployment. That rationale was arguably supported by the pre-existing disqualifications of "voluntary unemployment without good and sufficient reason" and "failure without good and sufficient reason to accept any offer of alternative employment", and this much seemed to be accepted by the Royal Commission. The function of the amendment must therefore be looked for elsewhere and, given the timing employed, it is difficult to avoid the conclusion that the Government's aim could be summed up in the rhetorical question posed by Professors Kahn-Freund and Hepple, "What is the denial of unemployment benefits ... if it is not an indirect compulsion to return to work?". (Kahn-Freund and Hepple (1976), p. 8) Despite the difficulties which might be inherent in the drafting of the amendment (e.g. the failure to define "place of employment") its passage provoked little opposition and the repeal of such provisions cannot be envisaged as a popular political cause.

\section{The Case Law Under Section 128}

Before examining the approach taken to section 128 by the Arbitration Court two general points may be made. The first is that, as presently drafted, the section raises the familiar spectre of the floodgates of litigation being opened. This is no novel phenomenon in New Zealand's industrial relations law as the events leading up to the 1978 Dunlop Report on the Freezing Industry indicate. In the case of section 128 the potential for a "flood" of claims being brought before the court arises from the drafting of subsection 3 of that section, whereby where any worker is suspended "he or any union representing him" may appeal to the Arbitration Court against the suspension. Together with section 117 subsection $3 \mathrm{~A}$, which gives workers the right to pursue a personal grievance individually in certain circumstances, the right of individual workers to appeal to the court under section 128 forms an exception to the general rule that individuals have no locus standi under the Act. Where appeals have been lodged by unions under the section, the tendency has been to put forward a test case; however the court has pointed out that such test cases do not determine the rights of those workers who were suspended but whose appeals have not been heard. ${ }^{1}$ Thus it appears desirable for the workers concerned to bring individual cases. Such cases must, in order to reach a conclusion, be considered separately; ${ }^{2}$ some involve more than 100 workers. ${ }^{3}$ The Arbitration Court has not yet been called upon to hear individual claims involving such numbers but if it was so called upon the attendant difficulties can easily be imagined.

1 See e.g. Canterbury Rubber Workers IUW v Firestone Tire and Rubber Company Limited (1977) Ind. Ct. 53 and New Zealand Federation of Wood Pulp etc. Workers Incorporated v New Zealand Forest Products Ltd (1978) Ind. Ct. 31.

2 Jamieson J. in Whitehouse and Others v Ford Motor Company of New Zealand I.td (1978) Arb. Ct. 287.

3 This was the position in the New Zealand Forest Products case, note 12 below. Though in the Canter. bury Rubber Worker's case note 1 above, Jamieson J. noted that "it is no doubt true that the men fall into several groups and that within each group the facts applicable to individual workers are identical" (at p. 55). 
The second general point is that section 128 has little practical value when the employer is confronted by certain forms of rolling strike, even though one reason for the 1976 amendment was the alleged difficulty posed by this form of industrial action; for present purposes the "rolling strike" may be described as "the action of a number of workers, acting in concert or pursuant to a common understanding, in striking in relay" (this being the definition supplied by section $119 \mathrm{C}$ subsection 3 of the Commerce Amendment Act 1976). For the purposes of section 128, "strike" must have the meaning given to that term under section 123 of the Industrial Relations Act. Under that section it has been held that if labour is withdrawn e.g. on certain days but not on others, there is a separate strike on any day or series of consecutive days on which labour is withdrawn; however the workers involved are not to be regarded as on strike on the days when normal work is carried out. ${ }^{4}$ The shorter the period of time involved in each separate "strike" within the overall "rolling strike", the less effective action under section 128 will be since the only right conferred by that section is to suspend non-striking workers and such suspension "can only last until the end of the strike concerned at the time of the suspensions". 5 It might be said also that, dependent upon individual industrial circumstances, the shorter each "strike" within the relay the less likely it is that the supply of normal work will cease as a result of the action.

Perhaps because of the inroads made by section 128 on established contractual principle concerning suspension, the Arbitration Court has emphasised that "The employer who wishes to use the power to suspend must be careful to keep within the provisions of [the section]". This view is echoed by the New Zealand Employers' Federation which has advised its members that section 128 should be used only where there is no other option and not "as a strike-breaking exercise". (New Zealand Employers' Federation, 1979) Nor is it open to the employer who suspends workers to argue before the court in the alternative under section 128 and the common law if the employer has purported to act in exercise of power which is claimed to be derived from section 128. So in Whitehouse and others v The Ford Motor Company of New Zealand Limited, where the employer "suspended" workers citing section 128 as justification but put forward an argument before the court based upon the common law right to suspend, Jamieson C.J. held that "The Court ... must look at the events which took place at the time. We are satisfied that ... the company ... purported to act in exercise of the power which it claimed to derive from section 128 . The matter must consequently be approached on that basis". 7

Under subsection 1 of section 128 in order for suspension of non-striking workers to be valid it is necessary first that there be a strike, secondly that the inability to provide work that is normally performed by those workers arises as a result of the strike and, thirdly, that the suspension of employment lasts only so long as the strike exists. Each of these elements has caused difficulty. The first question is whether a strike exists; since section 128 subsection 1 commences with the words "Where there is a strike" it follows that, before the employer can suspend non-striking workers, there must be a strike in existence at the time notices of suspension are given. In the Feltex Carpets (NZ) Ltd case notice of strike action was given by the Secretary of the Engine Drivers Union, to take effect on

4 The phraseology is taken from the headnote to the judgment of Chilwell J. in Harder v New Zealand Tramways etc Employees IUW [1977] 2 NZLR 162; see especially pp. 167-169.

5 Jamieson C.J. in New Zealand Engineering etc. IUW v New Zealand Steel Limited (1978) Arb. Ct. 131 at p. 133.

6 Jamieson C.J. in Wellington District Woollen Mills etc. IUW v Feltex Carpets (NZ) Limited (1978) Arb. Ct. 59.

7 (1978) Arb. Ct. 287 at page 288. Compare the New Zealand Steel case, note 5 above, where the employer made it clear from the start that the power being exercised was a right to suspend at common law and the discussion in the Feltex Carpets (NZ) Limited case, note 6 above, where it was unsuccessfully argued that a section 128 notice could amount to a 'constructive notice' that no work was available where a proper notice under the relevant award would have entitled the employer to suspend workers. 
Friday 9 December 1978 and possibly the following Monday. Operation of the employers' dyehouse was dependent upon members of the Engine Drivers Union working normally. On Thursday 8 December the employers issued notice of suspension to dye-house workers to take effect from 4.30 p.m. that day until 8.00 a.m. on the following Tuesday. The Arbitration Court held that there was never a valid suspension since "there was not, on the Thursday afternoon, a strike in existence". 8 Similarly where an employer dismissed eight men for being parties to a strike and then purported to suspend under section 128 a further 90 men for whom it was unable to provide work as a result, it was held that the suspensions were invalid; when the non-striking workers were suspended the strike was at an end since every one of the strikers had been dismissed.9 As previously stated the "rolling strike" may well create problems for the employer here since the commonly accepted analysis of that form of industrial action is that, legally speaking, it consists of a series of individual strikes; each one of these may begin and end in a short period and, under section 128, it is arguable that suspensions may neither precede nor outlive each single "strike" within the overall framework of the stoppage.

The remaining issue is the availability of normal work. In Whitehouse and others $\mathrm{v}$ The Ford Motor Company of New Zealand Limited a strike by boiler attendants led to suspensions throughout the respondents' Motor Vehicle Assembly Works. The three cases considered by the court were brought by men who had "work in hand" when they were suspended. However the suspensions were carried out because, the employer argued, "if men were allowed to continue working they might, when the plant resumed work after the strike, be idle for a time until the work flow caught up with them". The Arbitration Court expressed the view that this argument was not available under section 128 since the question was "whether, at the time of suspension, the employer was able or unable to provide work normally done by the worker .... . Suspensions should be withheld until it is clear that it is no longer possible to provide the worker with normal work". ${ }^{10}$ Jamieson C.J. pointed out that if there is a premature suspension "the Court cannot judge or even speculate as to how long the normal work could have been maintained". In similar circumstances an argument that prematurely suspended workers might be ordered to be paid "up to the point at which ... work listed would have run out as if they had been suspended at that point" was rejected by the Industrial Court on the basis that such premature suspensions were a nullity: suspensions "on a mass basis and not group by group as available work ran out" was described as "a course fraught with danger". ${ }^{11}$ It may be that such premature suspensions are precipitated by an employer's realisation that what work remains would constitute less than full-time employment. However it appears that, in order to amount to "work that is normally performed" under the section, the work available need not be such as to amount to full-time employment. The leading case is the recent decision of the Court of Appeal in NZ Forest Products Limited v The Northern etc Woodpulp, Paper and Related Products $I U W^{12}$ The case concerned a strike by maintenance unions at the Kinleith plant of New Zealand Forest Products. Certain workers, including an oil compound attendant, were suspended although they had not participated in the strike. At the time the oil compound attendant was suspended one of his duties (the periodic accounting of withdrawal of supplies from the oil compound) could have been continued and there were also "some operations ... which he may normally have been expected to do". These functions would probably have been less than full-time employment for the worker. In the Arbitration

8 Note 6 above at p. 61 . 9 Waitaki New Zealand Refrigeration Limited (Finegand Works) v The New Zealand Meat Processors
etc IUW (1977) Ind. Ct. 149.

10 Note 2 above, at p. 290 . Emphasis added.

11 North Island Electrical etc IUW v Carter Oji Kokusaku Pan Pacific Ltd (1977) Ind. Ct. 155.

12 Unreported, Court of Appeal, 27 May 1981 (C.A. 181/80) an appeal from the decision of the Arbitration Court in the Northern etc Woodpulp, Paper and Related Products IUW $\mathrm{v}$ New Zealand Forest Products Limited (unreported, Arbitration Court, Rotorua, 10 October 1980, A.C. 129/80, D.R. 41/80). 
Court, Horn C.J. held that the worker's suspension was "possibly premature and ... should not have taken place for the whole time over which it occurred". The employer appealed.

In the Court of Appeal Cooke J., delivering the judgment of the Court, re-iterated that it was "at the time when an employer invokes the section that the lawfulness of the suspension must be judged" and remarked that a reasonable degree of foresight and advance consideration must be called for on the part of an employer to enable the section to be operated as Parliament must have intended. On the main issue, namely whether the suspension was valid even though some normal work was available, Cooke J. stated that:

A section of this kind has to be applied in a practical way. If it can be foeseen that some normal work will be available but that there will be less of it than usual because of the strike, it must be a question of fact and degree whether there will be enough normal work to make it reasonable to keep the worker on. We reject two extreme interpretations: on the one hand, that the unavailability of a small amount of normal work will be automatically enough to justify suspension; on the other hand, that the availability of a small amount of normal work will be automatically enough to rule out suspension. The decision of the Arbitration Court in this case, although not expressed in the clearest of terms, is consistent with what we regard as the correct approach - namely that the matter is one of fact and degree and reasonable foresight.

The Arbitration Court was held to be entitled to reach the conclusion it did on the facts, in what Cooke J. described as a "borderline" case. Thus it is now clear that the section will not be interpreted so that suspensions can only take place as from the time when no work is available although, with respect, labelling the matter one of "fact and degree" means that the doubt as to the meaning of "work that is normally performed" remains. Is the question of whether it is "reasonable" to keep workers on to be viewed from the standpoint of the employer, the workers concerned, or an impartial observer? In requiring "reasonable foresight" on the part of the employer ("bearing in mind that the overall facts relating to the employer's operation would be peculiarly or mainly within the knowledge of the employer"), the Court of Appeal appear to consider that the issue must be judged from the employer's position. Nevertheless, the requirement of reasonableness injects some objectivity into the assessment and the general approach places some onus on the employer at the hearing. It is, perhaps, significant that Cooke J. referred to "normal work" (as did Horn C.J.) rather than adhering strictly to the statutory wording of "work that is normally performed". It is deceptively simple to see "normal work" in terms of "full-time work" or "almost full-time work". But on a strict approach "work that is normally performed" may well fall far short of provision of full-time work in circumstances quite independent of strike action (e.g. "standbys" occurring as a result of bad weather or power failure). This being so, is it really so "extreme" an interpretation to view the statutory wording as meaning that workers cannot be suspended until no work normally performed by them is available?

\section{Workers' Rights Under Section 128}

The rights of a suspended non-striking worker are set out in subsections three and four of section 128. Either that worker, or any union representing him or her, may appeal to the Arbitration Court against the suspension; notice of intention to do so must be given to the employer within 14 days after the date on which the worker received notice of the decision to suspend, and must be given to the Arbitration Court within seven days after that notice. On appeal the Court may confirm, reverse or modify the decision appealed against and may make such other order as it thinks just. Whilst grievances concerning suspension as such potentially fall within the dispute of rights procedure or personal grievance procedure under the Act the Court has made it clear that where the suspension is purported to be made under section 128 , the worker or union concerned should seek redress under that section. Exception has been made (by way of exercising the Court's sweeping powers 
under section 229 of the Act to dispose of matters "according to the substantial merits and equities of the case") where the matter has been referred to the disputes committee by both parties. ${ }^{13}$ It is apparent, nonetheless, that the discretion will rarely be employed. ${ }^{14}$ Therefore care must be exercised by applicants bearing in mind the time limits under section 128 , which have no counterpart under sections 117 and 116 , particularly in view of the need for each individual worker's case to be considered separately.

In addition, in the New Zealand Forest Products case, the Court of Appeal held that the onus in appeals against suspension of non-striking workers lies on the union: there is no onus on the employer to justify the suspension, although once evidence is brought to suggest that some normal work would be available during the suspension period the Arbitration Court is "free to take the view that the evidential onus had shifted to the employer and that in the absence of further evidence from the employer the appeal should succeed". It was noted though that the wide powers of the Arbitration Court to admit and call for evidence under section 57(1) of the Industrial Relations Act 1973 "underline that often questions of onus may not be of much importance under the Act". However, unions will need to come to the hearing with as much evidence as they can gather on the issue of the availability of work that is normally performed at the time when the employer invoked the section. It will not be enough simply to appeal and wait to see what evidence the employer may provide.

Finally, whilst the court has wide powers under section 128 to make a decision "as it thinks fit" and under section 47 to make a decision "in equity and good conscience" this power must be exercised in a manner "not inconsistent with the statute, whether it be the Industrial Relations Act or any other statute". ${ }^{15}$ Thus no remedy is available if the employer has conformed with the requirements of the section; ${ }^{16}$ the most effective course of action which unions can take under the law when confronted by suspension of non-striking workers is to ensure that the employer has done so.

\section{References}

Hansen, B.D. (1974): "Industrial relations reform in New Zealand - comments on the Industrial Relations Act, 1973", Victoria University of Wellington law review, 7:300-329. Judgments of the Industrial Court and the Arbitration Court (abbreviated as Ind. Ct. and Arb. Ct.).

Kahn-Freund, O., and B. Hepple, (1976) Laws against strikes, London.

New Zealand Employers' Federation (1979), "Hiring, firing and suspension - a guide to employers", supplement to Employer March.

New Zealand Law Reports (abbreviated as NZLR).

New Zealand Parliamentary Debates (abbreviated as NZPD).

Reid, J., (1977) "Industrial relations amendments in 1976", New Zealand universities law review, 7: 384-397.

Report of the Royal Commission of Inquiry, "Social Security in New Zealand" (1972), Wellington.

Social Security Department (1970), "Suggested changes to present social security cash benefits legislation", Background paper 10 to the Royal Commission of Inquiry into social security, Wellington.

Szakats, A., (1977), "Amendments to industrial legislation: the Industrial Relations Amendment Acts and the Commerce Amendment Act", Otago University law review. 4: $107-117$.

Woods, N.S. (1977), The industrial relations amending legislation of 1976, Industrial Relations Centre, Victoria University of Wellington.

13 Waitaki New Zealand Refrigerating Limited case, note 27 supra.

14 See the Canterbury Rubber Workers' case, note 17, supra.

15 New Zealand Shop Employees' IAW v Attorney General and Others, unreported, Court of Appeal,

24 August 1972, C.A. 49/72, followed in the Ford Motor Company case, note below.

16 New Zealand Engineering, etc IUW v Ford Motor Company of New Zealand Ltd (1976) Inc. Ct. 201. 